\title{
Training Bahasa Inggris Dasar Peramu Wisata Untuk Forum Muda Berkarya (FMB) Desa Wisata Hijau Bilebante Kabupaten Lombok Tengah
}

\author{
Kamarudin *, Sugianto, Tawali, Fathurrahman Imran \\ Program Studi Pendidikan Bahasa Inggris, FBMB UNDIKMA \\ *Corresponding Author Email: kamarudin.ntbe@gmail.com
}

\begin{abstract}
This community service aims to improve knowledge, basic English skill for teenagers especially English for tour guide both theoretically and practically. This program involved the teenagers of Working Youth Forum (FMB) Bilebante Green Tourism Village, Central Lombok Regency. The method implemented planning, acting, and observing in which through giving the material presentation focusing on some materials such as; English for tourism, modal auxiliaries, eight parts of speech, and mini conversation practice realizing the materials given. The result of this community service revealed that the respondents were very enthusiastic and interest to participate actively within the process of the program given start from the first till the end. The capability of the respondents was also increase regarding on how to use English language expression for tour guide, vocabulary items, and become more confident. They expected the same program may be re-conducted or proceeded in another time since it has positive effect toward presentation, and their communicative English language skill.
\end{abstract}

Abstrak: Pengabdian kepada masayarakat ini bertujuan untuk meningkatkan pengetahuan, kemampuan dasar Bahasa Inggris pemuda/i terutama tentang Bahasa Inggris peramu wisata baik secara teori maupun praktik. Program ini melibatkan pemuda/i yang tergabung dalam (FMB) Desa Wisata Hijau Bilebante Kabupaten Lombok Tengah. Metode didalam pengabdian ini yaitu Planning, Implementing, dan Evaluating yang mencakup pemberian materi yang terdiri dari English for tourism, modal auxiliaries, eight parts of speech, mini conversation practice yang merealisasikan materi yang diberikan. Hasil dari program ini menujukkan bahwa responden sangat antusias and terrtarik dalam berpartisipasi secara aktif selama proses pelaksanaan progam pengabdian mulai dari awal sampai akhir. Kemampuan responden juga meningkat terkait dengan bagaimana menggunakan expressi Bahasa Inggris untuk peramu wisata atau tour guide, kosa kata, dan menjadi lebih percaya diri. Mereka mengharapkan kegiatan pengabdian yang sama dapat dilanjutkan kembali pada kesempatan yang akan datang karena memiliki dampak yang positif terhadap presentasi, dan kemampuan komunikasi Bahasa Inggris mereka.

\section{Article History:}

Received: 12-03-2021

Reviewed: 14-04-2021

Accepted: 24-04-2021

Published: 05-05-2021

Key Words:

Training, Basic

English Language,

Tour Guide.

Sejarah Artikel:

Diterima: 12-03-2021

Direview: 14-04-2021

Disetujui: 24-04-2021

Diterbitkan: 05-05-2021

\section{Kata Kunci:}

Training, Bahasa Inggris

Dasar, Peramu Wisata.

How to Cite: Kamarudin, K., Tawali, T., \& Imran, F. (2021). Training Bahasa Inggris Dasar Peramu Wisata Untuk Forum Muda Berkarya (FMB) Desa Wisata Hijau Bilebante Kabupaten Lombok Tengah. Jurnal Pengabdian UNDIKMA, 2(1), 91-97. doi:https://doi.org/10.33394/jpu.v2i1.3706

doi:https://doi.org/10.33394/jpu.v2i1.3706

This is an open-access article under the CC-BY-SA License.

\section{Pendahuluan}

Universitas Pendidikan Mandalika merupakan kampus tertua dan terdepan yang ada di Nusa Tenggara Barat (NTB) yang sampai saat ini terus berupaya menjalin mitra dengan seluruh eleman masyarakat baik yang ada di perkotaan maupun yang di perdesaan dalam rangka mendukung kemajuan kampus, baik secara langsung maupun tidak langsung. Dengan adanya dukungan penuh dari LPPMM Universitas Pendidikan Mandalika, dosen Bahasa 
Inggris FBMB melaksanakan sebuah pelatihan dengan judul 'Training Bahasa Inggris Dasar Peramu Wisata Untuk Forum Muda Berkarya (FMB) Desa Wisata Hijau Bilebante Kabupaten Lombok Tengah'.

Pelatihan tersebut terlaksana mengingat bahwa Pengabdian Kepada Masyarakat (PKM) tidak hanya bertujuan untuk mengimplementasikan hasil penelitian atau pembelajaran yang sudah didapatkan di kampus secara teoritis tetapi juga harus secara praktis di implementasikan kepada masyarakat secara lansung karena pengabdian adalah jembatan untuk menghubungkan dan mensukseskan tujuan pembelajaran yang sebenarnya yang ada di kampus dengan masyarakat pada umumnya (Rahmawaty, 2012).

Setelah melakukan observasi lapangan terkait situasi dan kondisi yang terdapat di tempat pengabdian ditemukan bahwa pemuda dan pemudi khususnya yang tour guide yang ada di Desa Wisata Hijau Bilebante Kabupaten Lombok Tengah sangat perlu diberikan dan dibekali dengan kemampuan Bahasa Inggris dasar peramu wisata secara umum. Ditemukan bahwa banyak diantara mereka belum sepenuhnya mengetahui dasar-dasar Bahasa Inggris khusunya untuk tour guide sehingga ketika ada tamu mancanegara yang datang berkunjung, tidak jarang dari mereka kesulitan menjelaskan objek wisata yang dikunjungi. Selain itu, hal tersebut perlu juga diberikan karena sebagaimana diketahui bahwa di era teknologi seperti saat ini, menguasai Bahasa Inggris bukan lagi sebuah trend tetapi sudah menjadi kewajiban bagi semua orang untuk mempelajarinya dan menguasainya. Terlebih lagi dengan perkembangan zaman yang serba modern ini, Bahasa Inggris digunakan sebagai alat untuk berkomunikasi dan interaksi mulai dari perkotaan sampai pedesaan. Hal ini terbukti dengan merambahnya koneksi Internet ke semua penjuru Desa yang membuat semua orang harus belajar Bahasa Inggris.

Untuk memenuhi kebutuhan tersebut, tim pelaksana kegiatan pengabdian pada masyarakat dari Fakultas Budaya Bisnis dan Manajemen (FBMB) melaksanakan training singkat yang bertujaun untuk memberikan pemahaman tentang dasar-dasar Bahasa Inggris untuk peramu wisata kepada peserta pelatihan.

Adapun target pengabdian ini kepada peserta pelatihan adalah memberikan pembelajaran dasar-dasar Bahasa Inggris yang berkaitan dengan dunia pariwisata khususnya peramu wisata atau tour guide. Sehingga secara khusus membahas istilah-istilah yang biasa digunakan dalam berkomunikasi dengan tamu maupun dengan orang lain. Dengan terselenggaranya pelatihan ini, diharapkan bahwa para peramu wisata atau tour guide yang tergabung dalam Forum Pemuda Berkarya (FMB) di Desa Wisata Hijau Bilebante Kabupaten Lombok Tengah memiliki kualifikasi berbahasa inggris yang memadai sebagai bentuk pelayanan optimal kepada masyarakat.

Proses pembelajaran dalam pelatihan ini diberikan berdasarkan materi yang sudah disusun dengan baik yang dimana berisi tentang English for Tourism khususnya membahas tentang Tour Guide. Materi tersebut tentu sangat dibutuhkan mengingat bahwa hal tersebut akan mendukung mereka untuk meningkatkan skill mereka dalam berbahasa inggris baik secara lisan maupun tulisan. Selain itu, untuk mewujudkan generasi mileneal yang berdaya saing, maka perlu dibekali dengan keterampilan Bahasa Inggris yang memadai sehingga mereka dapat bersaing baik dikancah nasional maupun Internasional. Tentu yang tidak kalah penting juga adalah untuk mendukung program Pendidikan pemerintah yaitu mencerdaskan kehidupan bangsa. Maka, dengan bekal Bahasa Inggris, generasi milenial tersebut khususnya pemuda-pemudi yang tergabung dalam FMB Desa Bilebante dapat ikut berkontribusi terhadap masyarakat sekitarnya. 
Melului pelatihan inilah diharapkan peramu wisata yang handal setidaknya dapat diwujudkan tentunya dengan tidak terlepas dari dukungan semua pihak sehingga apa yang menjadi target pelatihan ini berjalan dengan lancar. Tentunya dengan menguasai teknologi, cakap dalam profesi yang ditekuni, menguasai bahasa, terutamanya bahasa Inggris sebagai bahasa Internasional yang digunakan oleh hampir seluruh orang di dunia, adalah modal yang cukup untuk membentuk tenaga-tenaga pariwisata yang memiliki tingkat kompetensi yang tinggi dan membanggakan. Jadi, program pengabdian kepada masyarakat yang dikemas dalam bentuk pelatihan Bahasa inggris dasar peramu wisata ini sangat layak dan perlu untuk di dukung dan terus diselenggarakan sehingga dapat membantu masyarakat untuk mendapatkan pelayanan pariwisata yang memadai.

\section{Metode Pengabdian}

Untuk mensukseskan rangkaian kegiatan pengabdian yang ingin dilaksanakan, maka sangat diperlukan sebuah metode dengan tujuan kegiatan tersebut dapat bejalan dengan baik dan lancar. Metode serta mekanisme pelaksanaan kegiatan pengabdian pada masyarakat ini dilakukan dengan menggunakan tiga tahapan penting yaitu: Planning, Implementing, dan Evaluating (Sopian, 2012). Adapun penjelasan alur realisasi dari masing-masing tahapan dalam pelaksanaan kegiatan progam ini adalah sebagai berikut.

\section{a) Planning}

Planning merupakan rencana yang akan dilakukan dalam kegiatan ini yang bertujuan untuk kelancaran kegiatan yang akan dilaksanakan. Adapun tahapan planning pada kegiatan ini adalah sebagai berikut:

1) Mengurus izin tertulis dari kepala Lembaga Penelitian dan Pengabdian Kepada Masyarakat (LPPM) UNDIKMA, serta mendapat izin dari mitra dalam hal ini Forum Pemuda Berkarya (FMB) Desa Wisata Hijau Bilebante Kabupaten Lombok Tengah.

2) Meyusun rencana, strategi, modul dan juga materi yang akan diajarkan kepada para peserta pelatihan Bahasa Inggris Dasar Peramu Wisata.

3) Melakukan survey langsung kepada mitra dan berinteraksi langsung dengan para calon peserta training sebagai bentuk dari pengenalan awal dari program pengabdian yang akan diberikan kepada mereka.

\section{b) Implementing}

Setelah melakukan perencanaan dengan matang, maka tahap selanjutnya adalah implementasi dari rencana tersebut. Pada tahapan ini, tim pelaksana pengabdian malaksanakan beberapa kegiatan yaitu:

1) Pelaksana datang dan mengajarkan materi tetang English for Tourism khusunya for Tour Guide atau peramu wisata yang telah disusun sebelumnya

2) Memberikan materi tentang ekpressi-ekspressi Bahasa Inggris yang biasa digunakan oleh tour guide.

3) Memberikan modeling pengunaan conversation dalam Bahasa Inggris yang disertai dengan praktek peragaan English Conversation practice.

4) Memantau progress penyerapan materi yang telah disampaikan, serta sejauh mana materi mampu diserap dan diimplementasikan dalam bentuk yang lebih nyata yakni percakapan bahasa Inggris.

\section{c) Evaluating}

Setelah tahapan planning, dan implementing di lakukan, selanjutnya adalah evaluating. Tahapan ini bertujuan untuk mengukur sejauh mana materi ajar yang telah diberikan 
mampu diserap oleh para peserta pelatihan. Adapun rincian tahapan kegiatan yang dilakukan pada tahap evaluasi ini adalah:

1) Tim melakukan Assessment dengan memberikan soal berupa test kepada para peserta tentang semua point materi ajar Bahasa Inggris untuk tour guide yang telah diberikan oleh tutor.

2) Tim memberikan test praktek kepada para peserta dengan meminta mereka untuk mempraktekkan materi Bahasa Inggris yang pernah mereka pelajari secara peer practice.

3) Tim mencatat point-point yang masih dirasakan kurang terserap dengan baik dengan memperhatikan hasil test tertulis dan test praktek yang sudah mereka lakukan.

4) Melakukan tindak lanjut terhadap catatan khusus yang telah dibuat dengan memberikan pengulangan bagi para peserta yang masih belum menguasai materi yang disampaikan.

5) Memastikan bahwa target yang telah direncanakan apakah telah tercapai dengan maksimal atau belum.

\section{Hasil Pengabdian dan Pembahasan}

Kegiatan pengabdian yang dilakukan di Desa Wisata Hijau Bilebante yang ada di Kabupaten Lombok Tengah dengan tema 'Training Bahasa Inggris Dasar Peramu Wisata Untuk Forum Muda Berkarya (FMB) Desa Wisata Hijau Bilebante Lombok Tengah' dilaksanakan dengan tatap muka dan praktek ini berjalan dengan baik dan lancar sebagaimana yang diharapkan, tentunya tetap mengedepankan protokoler yang ada. Pertemuan tatap muka dilaksanakan dengan metode drilling/training yang kemudian dilanjutkan dengan praktek real communication. Pada bagian ini juga di deskripsikan hasil pengabdian dan pembahasan hasil pengabdian yang pernah dilakukan.

\section{Observasi Lapangan}

Pada tahap ini, tim pelaksana kegiatan melakukan observsi lapangan yang bertujuan unutk mengidentifikasi dan mengetahui situasi dan kondisi lapangan serta potensi yang ada dan memilih lokasi yang tepat untuk melakukan pelatihan. Selain itu, koordinasi dengna pihak terkait juga dilakukan yang dimana meliputi; penyusunan program pelatihan, dan sosialisasi program. Penyusunan program dilakukan berdasarkan jangka waktu kegiatan dan jumlah peserta. Program PKM ini dilaksanakan dalam jangka waktu delapan bulan dengan jumlah pertemuan 20 kali. Materi pemelajaran disesuaikan dengan tema kegiatan yaitu Bahasa Inggris yang focus pada pariwisata. Setelah penyusunan program, tim melakukan sosialisasi program kepada masyarakat di Desa Wisata Hijau Bilebante Lombok Tengah yang terdiri dari para pemuda/i. Setelah itu tim pelaksana program melakukan koordinasi dengan kepala Desa, kepala pengelola KKLD, dan tokoh masyarakat lainnya. Kepala Desa menyambut baik program PKM tersebut dan bersedia menyediakan sarana yang bisa disewa sebagai tempat kegiatan

Dari hasil observasi lapangan ditemukan bahwa peramu wisata khsusunya yang tergabung dalam Forum Muda Berkarya sangat membutuhkan keterampilan Bahasa Inggris untuk menunjang pengetahuan mereka dalam berkomunikasi menggunakan bahasa Inggris pada saat menjeleskan objek wisata kepada tamu. Untuk mendukungnya tercapainya target tersbut, salah satu upacaya yang dilakukan adalah dengan pemberian pelatihan baik via seminar atau yang lainnya. Hal ini sebabkan karena selama observasi awal terdapat banyak sekali peramu wisata yang masih belum mampu berkomunikasi atau terbatasnya kemampuan mereka dalam berbahasa Inggris dengan baik, sehingga mereka sangat terkendala ketika ingin mengaplikasikannya kedalam kehidupan mereka sehari-hari terutama pada saat 
berkomunikasi dengan orang asing. Oleh sebab itu, upaya edukatif sangat diperlukan untuk meningkatkan keterampilan komunikasi Bahasa Inggris mereka baik pada level nasional maupun internasional (Dira,dkk, 2020). Salah satu upaya yang dilakukan adalah dengan melakasanakan program pelatihan dasar-dasar Bahasa Inggris peramu wisata untuk Forum Muda Berkarya Desa Wisata Hijau Bilabante Kabupaten Lombok Tengah.

\section{Tindakan Pelaksanaan Kegiatan Pelatihan}

Pada tahap Tindakan ini, ada tiga kegiatan yang telah dilaksanakan yaitu; a) pembentukan kelompok peserta pelatihan, b) pemberian materi, dan c) pengaplikasian materi. Kelompok dibentuk berdasarkan kemampuan masing-masing peserta yang dimana mereka terlebih dahulu diberikan placeman test. Peserta yang berprofesi sebagai peramu wisata, sebagian besar diantaranya merupakan lulusan SMU sederajat. Sedangkan para pemuda/i beberapa diantaranya merupakan siswa SMU/ sederajat. Total peserta berjumlah tiga puluh orang. Setelah kelompok terbentuk, mereka diberikan materi Bahasa Inggris pariwisata yang konteksnya sesuai dengan pekerjaan mereka yaitu sebagai peramu wisata dan persiapan menjadi pemandu lokal. Dalam pembelajaran, setelah mereka menerima teori, mereka diminta untuk mempraktekkan materi dalam bentuk percakapan. Selain materi Bahasa Inggris, peserta juga dibekali dengan Teknik kepemanduan. Harapannya ketika makin banyak wisatawan yang datang khususnya wisatawan mancanegara ke Desa Wisata Hijau Bilebante Kabupaten Lombok Tengah, mereka bisa mengambil peran sebagai pemandu lokal. Berikut foto pelaksanaan program PKM yang telah dilaksanakan.

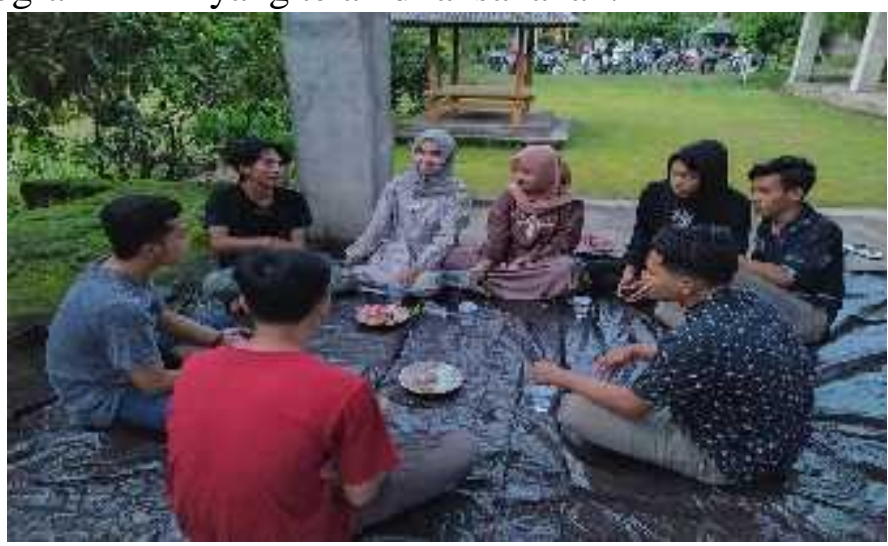

Gambar 1. Diskusi dengan Kelompok tentang Materi yang Diberikan

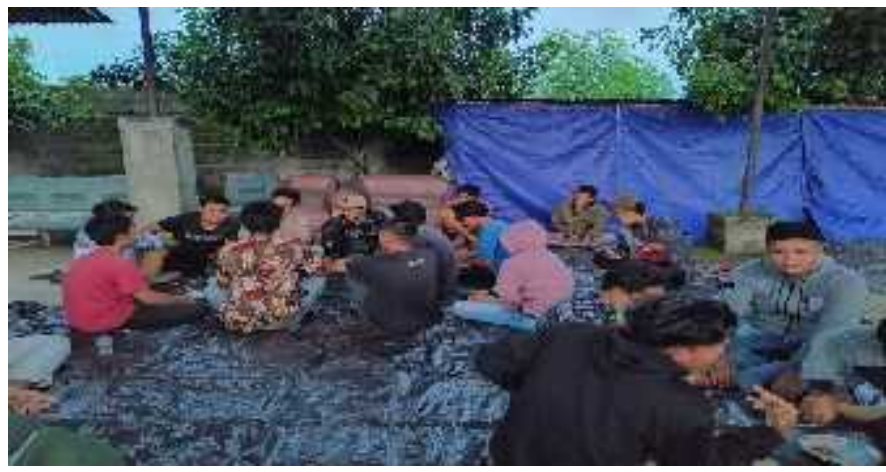

Gambar 2. Praktik Conversation Menggunakan Bahasa Inggris 


\section{Evaluasi Kegiatan}

Adapun tahapan refleksi dan evaluasi bertujuan untuk meningkatkan kualitas dan sekaligus mempelajari kelebihan dan kelemahan dari program yang telah dilaksanakan yang nantinya dapat digunakan sebagai acuan untuk program-program selanjutnya. Selama proses pelatihan, tim pelaksana kegiatan pengabdian melakukan pemantauan kepada peserta pelatihan sekaligus melakukan wawancara terhadap materi, metode dan instruktur dalam kegiatan ini. Secara umum para peserta mengatakan pelatihan ini sangat baik dan materi yang diberikan merupakan materi yang sangat dibutuhkan dalam parawisata sedangkan instrukturnya sangat berkompoten.

Adapun beberapa hasil yang didapatkan setelah melakukan kegiatan training ini adalah: a) kegiatan pelatihan berjalan dengan lancar sesuai dengan yang diharapkan; b) peserta pelatihan menunjukkan minat belajar yang kuat selama mengikuti proses pelatihan; c) peserta pelatihan dapat menunjukkan perbaikan dalam hal penguasaan materi serta keterampilan berkomunikasi menggunakan bahasa Inggris dengan baik selama praktik yang diberikan dan pendampingan. Hal tersebut terlihat dari meningkatnya self-confident peserta yang meningkat lebih baik dari sebelumnya.

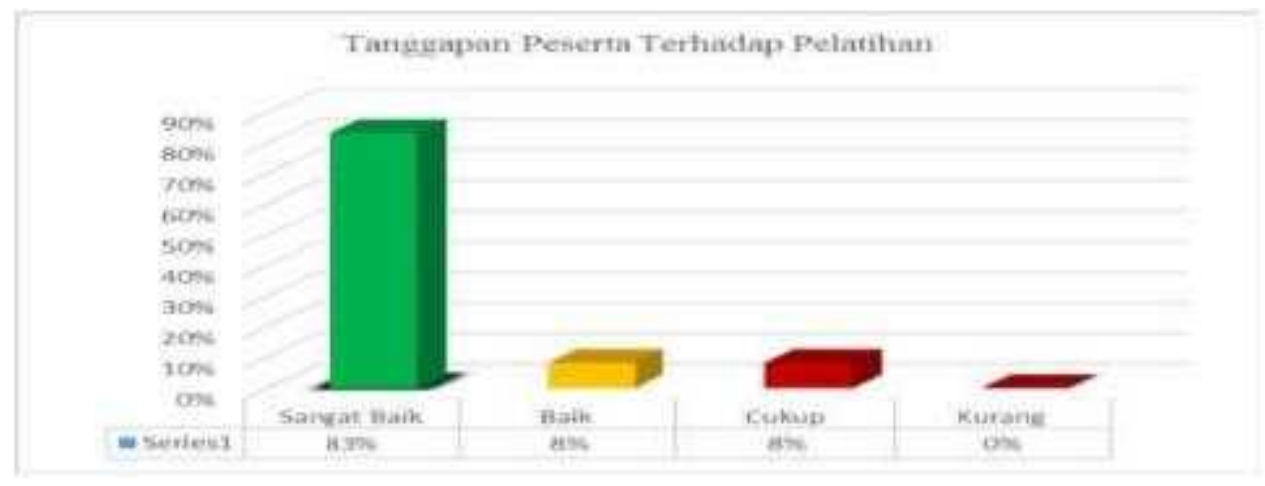

Gambar 3. Tanggapan Peserta Terhadap Pelatihan

Melalui implementasi program ini, peserta pelatihan menjadi lebih sadar terhadap pentingnya skill berbahasa Inggris khususnya dalam hal pariwisata karena selain mendapatkan kemudahan dalam berkomunikasi dengan orang asing, juga dapat memahami teks-teks yang berhabasa Inggris. Mereka dapat mengetahui informasi yang akan disampaikan pengunjung yang datang ketempat mereka menggunakan Bahasa Inggris dengan lebih mudah. Oleh sebab itu, sangat diharapkan akan adanya tindak lanjut yang bersifat lebih besar lagi terhadap pelatihan ini sehingga dapat melibatkan peserta yang lebih banyak lagi. Tentu hasilnya akan dirasakan lansung oleh masyarakat terlebih lagi oleh peserta training pada khususnya.

\section{Kesimpulan}

Berdasarkan kegiatan pengabdian kepada masyarakat ini diperoleh kesimpulan bahwa pelaksanaan kegiatan tersebut berjalan dengan lancar dan baik sesuai dengan apa yang direncanakan. Peserta pelatihan khususnya yang tergabung dalam FMB dapat menunjukkan peningkatan dalam hal penguasaan materi yang diberikan serta dapat mempraktikkannya dengan baik. Dan peserta juga sangat antusias dalam mengikuti traning dan mengapresiasi kegiatan tersebut dengan baik. Hal tersebut terbukti dari hasil angket yang diberikan tentang tanggapan mereka terhadap pelatihan itu menunjukkan $83 \%$. Selain itu, kemampuan mereka juga meningkat terlihat pada saat melakukan praktik conversation menggunakan Bahasa Inggris yang berkaitan dengan masalah pariwisata dan peramu wisata. 


\section{Saran}

Adapun saran yang disampaikan berdasarkan hasil kegiatan pengabdian ini adalah tim pengabdian sangat menyarankan bahwa kegiatan serupa dapat dilaksanakan kembali pada waktu, tempat dan scope yang lebih besar dan bahkan ditempat yang berbeda dengan tujuan untuk memberikan pemerataan sehingga tidak hanya masyarakat Desa Bilebante Kabupaten Lombok Tengah yang dapat merasakan dampaknya, tetapi juga Desa atau tempat lain juga bisa merasakan keberhasilan yang dirasakan oleh masyarakat Bilebante tersebut.

\section{Daftar Pustaka}

Asep Sopian. (2012) Training Penyuluhan Keagamaan di Kabupaten Subang. Kampus Purwakarta.

Kamarudin, K., Haerazi, H., Sugianto, S., Imran, F., \& Tawali, T. (2020). Implementasi Program Mini-Seminar Bahasa Inggris Bidang Kesehatan Untuk Program Studi Kesehatan Masyarakat Undikma Mataram. Jurnal Pengabdian UNDIKMA, 1(2), 160165. doi:https://doi.org/10.33394/jpu.v1i2.3084

Permana, D., Qomariyah, S., \& Rizka, M. (2020). Pelatihan Keterampilan Berkomunikasi Bahasa Inggris Bagi Pramusaji Kedai di Kawasan Wisata Aik Berik. Jurnal Pengabdian UNDIKMA, 1(1). doi:https://doi.org/10.33394/jpu.v1i1.2546

Tim. (2016) Panduan Pelaksanaan Penelitian dan Pengabdian Kepada Masyarakat di Perguruan Tinggi Edisi X. Direktorat Jenderal Pendidikan Tinggi Kementerian Pendidikan dan Kebudayaan.

Penny Rahmawaty, et al. (2012) Pemberdayaan Usaha Ekonomi Produktif bagi Masyarakat Miskin di Kota Yogyakarta. Universitas Negeri Yogyakarta.

Tim. (2013) Panduan Pelaksanaan Penelitian dan Pengabdian Kepada Masyarakat di Perguruan Tinggi Edisi IX. Direktorat Jenderal Pendidikan Tinggi Kementerian Pendidikan dan Kebudayaan. 